\title{
Urban Demolition: Application of Blight Elimination Programs and Flood Buyout Programs to the Italian Case
}

\author{
Simone Rusci ${ }^{1, *}$, Diego Altafini ${ }^{1}\left(\mathbb{D}\right.$ and Valerio Di Pinto ${ }^{2}(\mathbb{C}$ \\ 1 Dipartimento di Ingegneria dell'Energia, dei Sistemi, del Territorio e delle Costruzioni, DESTeC, \\ Università di Pisa, 56126 Pisa, Italy; diego.altafini@phd.unipi.it \\ 2 Dipartimento di Ingegneria Civile, Edile e Ambientale, Università di Napoli Federico II, 80138 Naples, Italy; \\ valerio.dipinto@unina.it \\ * Correspondence: simone.rusci@unipi.it; Tel.: +39-050-221-7768
}

check for updates

Citation: Rusci, S.; Altafini, D.; Di Pinto, V. Urban Demolition: Application of Blight Elimination Programs and Flood Buyout Programs to the Italian Case. Sustainability 2021, 13, 9412. https: / / doi.org/10.3390/ su13169412

\section{Academic Editors:}

Raúl Romero-Calcerrada, Javier Cabello,

Manuel Pacheco-Romero and Koldo Trapaga Monchet

\section{Received: 8 July 2021}

Accepted: 18 August 2021

Published: 22 August 2021

Publisher's Note: MDPI stays neutral with regard to jurisdictional claims in published maps and institutional affiliations.

Copyright: (c) 2021 by the authors. Licensee MDPI, Basel, Switzerland. This article is an open access article distributed under the terms and conditions of the Creative Commons Attribution (CC BY) license (https:/ / creativecommons.org/licenses/by/ $4.0 /)$.

\begin{abstract}
In recent years, there has been a growing awareness that not all decommissioned and obsolete real-estate assets can be recovered and reused. After the paradigm of urban growth, and following the paradigm of regeneration, a new paradigm seems to be looming on the horizon: the paradigm of shrinkage. Due to this change in perspective, discussions on the potential of demolition policies as an alternative to regeneration and reuse are gaining support in the debate about urban growth. In the United States, there are two on-going programs using demolition as their main tool for urban planning: the blight elimination programs and the flood buyout programs. The former foresees the demolition of abandoned and decayed real-estate assets, while the latter envisions the demolition and relocation of buildings within areas under flooding risks. Given their successful employment in the U.S., this paper evaluates the applicability of these programs to an Italian case, which is characterized by a different building heritage and different territorial conditions. Simulations of the programs' application are made using two case studies: Lecce nei Marsi (Abruzzo) and Moncalieri (Piemonte). The results demonstrate the substantial feasibility of the blight elimination programs' usage in Italy, while the flood buyout programs instead demonstrates major obstacles that may hinder its successful application.
\end{abstract}

Keywords: urban demolition; contraction; real-estate; landscape

\section{Introduction}

Decommissioning and demolition of no longer used real-estate assets have, in recent years, gained emphasis in urban planning debates, both as a conceptual issue and regarding their implications as policies and planning instruments. After an extensive period where urban growth was based on diffuse patterns [1], globalization processes have produced locational polarizations that deprived several regions of function and population, and made evident the interrelations among the demands on planning for both growth and shrinkage [2].

In the United States, the need for an intervention in decommissioned real-estate assets became evident in the late 1970s, due to a redefinition of geographies and production patterns; public programs were started with the objective of removing underused, as well as abandoned, residential and productive real-estate. In that regard, these blight elimination programs (BEP) [3] were the first to admit that urban growth could not only be reduced, but also inverted, leading cities to a process of contraction in which the habitual policies of regeneration and repurposing would prove to be fragile and inefficient. Still, until the early 2010s, such scenarios of contraction represented an exception within a global context that-albeit with different intensities - continued to exhibit overall urban growth. However, the fruition phase of globalization-influenced growth culminated with the real-estate crisis of 2007, that demonstrated that the rise in property demand, otherwise assumed to be an everlasting constant in economics, could not be sustained and, above all, supported in a 
spatially diffuse pattern, which led to wide gaps in-between different territorial contexts. In the United States, the recognition that demolition - thought of as an urban subtractioncould be an instrument of public policies has highlighted the potential for new applications in contexts that are distinct from those regarding cities in contraction. In this approach, the flood buyout programs (FBP) [4] (initiatives focused on the removal of properties within hydrogeological risk areas) employ demolition as a form of prevention of post-emergency costs. In recent decades, Europe has also experienced intense urban shrinkage dynamics that have affected both medium-and large-sized cities (as, for example, in the former East Germany) and former industrial territories and inland areas. In contrast, the dominant paradigm in the United States has so far been that of urban redevelopment $[5,6]$, i.e., investment in existing assets for their demolition and reconstruction or for their recovery and reuse. Although this approach is undoubtedly preferable, the economic conditions of the territory do not always allow for its implementation. In many Italian areas, the market values are lower than the costs of renovation and new construction, making any real-estate investment economically unsustainable, even for simple building renovations. In these contexts, which become more and more diffused, urban regeneration strategies cannot be realized, since they lack economic sustainability. Hence, a public strategy for the management of decommissioned real-estate assets with the aim of mitigating and reducing the negative externalities produced by them is essential.

With these points in consideration, this paper intends to open a discussion on the possible strategies for the demolition and removal of buildings, in order to fill the gap that exists in the literature regarding the Italian case and, albeit less markedly, European cases as well $[7,8]$. The purpose is not so much to propose or evaluate demolition policies, but instead to analyze the economic prerequisites and their overall feasibility of implementation in the Italian case, given the recognized socioeconomic characteristics and constrains. Therefore, simulations of both BEP and FBP programs for two Italian contexts characterized by abandonment and flood risk are made, with an evaluation of their projected costs.

In spite of the marked differences between the Italian and the US contexts, the two programs were chosen for three reasons: (i) They are the only public programs based exclusively on demolition actions, without the prospect of reuse of the areas for urban purposes; (ii) They have been applied for over 30 years and the effects and implementation procedures have been monitored; (iii) Reliable data on the costs incurred for their implementation are available.

The interest of simulating these programs for Italian cases is based on the growing presence of a vast stock of decommissioned real-estate assets, as well as of real-estate under risk conditions, for which neither regeneration nor risk mitigation strategies seem to be feasible. The conditions of applicability of the two programs to the Italian case are circumscribed to those contexts in which widespread urbanization prevails, with buildings and lots belonging to single owners in which it is possible to act punctually (i.e., to conditions closer to those found in the US urban structure). In Italy, these conditions can be found both in small historical settlements of agricultural origin and in the more recent suburban developments surrounding the metropolitan centers. The former are urban areas often characterized by abandonment, while the latter are characterized by the presence of flooding risk.

The simulation returns different results for the two programs: the blight elimination programs appear to be economically commensurate with the financial capacity of the local administrations and further technical and regulatory studies could, in the near future, lead to their application to the Italian case. Where regeneration is not economically feasible, a system of incentives for removal could bring significant benefits in environmental and social terms, in addition to enhancing the value of properties adjacent to those abandoned. On the other hand, due to the typological and constructive nature of the Italian building heritage, flood buyout programs tend to be excessively expensive and their commitment in terms of public resources is comparable to the expenditure that would be incurred with interventions aimed to mitigate the environmental risks. 


\section{Demolition as an Urban Policy}

Over the last century, globalization processes prompted important transformations in territorial and urban structures, as well as in their intrinsic dynamics [2,9]. While several cities have lost their inhabitants, laborers, and manufacturing activities, others have, instead, observed a sudden growth and are now considered global metropolises. This flow of population and economic activity between cities and territories has given rise to two closely intertwined effects: the hypertrophic expansion of metropolitan boundaries, which often obtrude areas under the risk of natural disasters, and, in parallel, the abandonment of smaller town centers and isolated real-estate assets, which were once used for local agriculture, manufacturing, and services. These divergent and often dichotomic territorial conditions resulted in urban areas with extensive population and productivity growth, in contrast to vast territories that are characterized by economic stagnation and demographic contraction.

In both cases, these novel locational conditions, associated with periodical transformations in the productivity systems, created an ample and heterogeneous collection of obsolete or decommissioned real-estate assets, constituted of structures built in different periods with distinct purposes. Urban centers under expansion had better conditions to stimulate the recovery and regeneration processes capable of reconverting-or replacing-the abandoned heritage buildings, with real-estate initiatives supported by market dynamics and the positional income from that urban land. In the other cases, regeneration and reuse methods have, instead, encountered a restricted or absent local demand, unable to cover the costs of reconversion or the attribution of new functions to decommissioned real-estate assets. This links the ongoing dire context of urban contraction, commonly referred to as economic decline, with growing unemployment and the related effects on private and public urban real-estate, with the permanence of obsolete buildings, which set in motion the phenomena of physical, social, and environmental decay.

The recognition that not every decommissioned or obsolete real-estate asset can be regenerated has introduced-first in the United States and, more recently, in Europe-a rationale regarding the role that demolition can have in public policies, serving as an instrument of a planned intervention alternative to the usual programs of regeneration or reuse. The well-known case of Detroit and, more generally, the cities from the American Rust Belt, have established an experimental laboratory for these programs and for this field of research since the 1970s [10,11]. Until those initial experiences, the decline of demolition as an urban policy was anything but obvious, since, within the urban expansion paradigm [1] prevalent throughout the 20th century, removal had only an additive meaning, employed as a temporary intervention that opened space for further urban expansion, and never represented a permanent real-estate assets' subtraction. If cases such as post-war reconstruction are considered [12], demolition as a programmed action towards realestate was restricted to two typologies of mediation: (i) Demolition as a form of repair; (ii) Demolition as an initial condition for new buildings construction.

The case first mentioned above includes all of these interventions, in that the removal is interpreted as the final stage of the structure lifecycle [13,14], and has the eliminate situation involves of danger, decay, or illegality. This repair-oriented demolition was used to secure non-utilized buildings characterized by a physical and structural obsolescence [15,16], as means to ensure economic recovery of the urban surroundings through increments in real-estate values [10], or the restoration of legal conditions in situations where the construction was in infringement of building regulations [17]. In the second case, frequent in expansion contexts, demolition does not represent the end of the processes, but consists of an intermediate step that precedes the remodeling or complete reconstruction of the structure. Several regeneration (a broad term that covers large to small-scale works aimed at improving the quality of life), restoration (i.e., a set of actions aimed at returning a building to its former state, while also maintaining its heritage and culture value in the case of historical buildings), and building replacement (i.e., the construction of a new building in place of a previous one with different or inadequate characteristics) interventions are part of 
this case, in which demolition is nothing more than a technical and economic component in the novel construction process [18]. In both these cases, however, the demolition intervenes in a timely and limited manner on the real-estate assets, with a specific and often monoobjective purpose. Sporadic Cases where demolition has assumed the role of public policy or is coined in a widespread action on similar territorial conditions through integrated and multi-objective interventions are sporadic. In this latter context, some demolition policies can be distinguished as a response to specific urban conditions. Such is the case of the blight elimination programs from the United States [3], or Nashville's Buyout Program [4], which is analyzed further in this paper. Under these circumstances, demolition is used to intervene on real-estate assets that have a common condition regarding their critical status, namely that their social or environmental influence on their urban surroundings create negative externalities that justify their removal [19]. Hence, this approach recognizes in demolition a regenerative property, that can qualify and recover the urban context [10].

In recent years, demolition policies are oriented to respond to a more general need in managing urban contraction and the "real-estate waste" caused by it, therefore, they are no longer only used as a response to sectorial problems, but as a real tool for the definition and redefinition of urban form, space, and landscapes; they are an opportune urban and landscape form of repair that can be applied, for example, in diffuse cities [20], in obsolete tourist settlements, or in some contexts with particular landscape value. At the same time, the recognizable economic and administrative difficulties in implementing these actions have prompted assessments on the possibility of managing obsolescence without resorting to demolition, allowing the coexistence of abandoned buildings with buildings still in use. In this sense, some ecogenesis management strategies are outlined, comprised by actions of progressive controlled renaturalization, which arrive at suggestive definitions of "ruins of contemporaneity" [21] or "third landscape" [22] that intend to attribute figurative and ecological value to the abandoned real-estate assets while preserving the residual value that could be reactivated in long-term cycles and processes.

\section{Two Themes: The Decommissioned Real-Estate Assets and the Under-Risk Real-Estate Assets in Italy}

Demolition as a territorial policy is a particularly pertinent theme in Italy, regarding two specific categories of real-estate assets: the decommissioned and obsolete assets and the assets that, although already in use, are located within areas with elevated environmental risks. These conditions, albeit marginal, present several issues that concern the safety of the population, the environmental and landscape quality, and, above all, the economic value of these and the surrounding structures.

The first group of real-estate assets analyzed corresponds to those that are decommissioned or abandoned, thus in a situation of decay. According to the last census from the Istituto Nazionale di Statistica (ISTAT) [23], the total number decommissioned real-estate assets in Italy comprise 744,435 structures, or $5 \%$ of the national total-a number to which ought to be added several public and private properties that, even though underused or abandoned, are not formally categorized as such. Of these structures, circa 70,000 comprise historical heritage buildings (castles, mansions, and villages), while the rest is composed of real-estate assets with productive uses (circa 130,000), and a mix of residential and other uses, constructed for the most part throughout the second half of the 20th century. Since up-to-date census statistics on decommissioned buildings are not available, the real-estate assets unable to generate value due to their state of decay can be identified through the Italian Land Register survey, where these structures are categorized as unità collabenti (F2 category). In 2018, 547,544 units, an equivalent of $0.8 \%$ of the total properties recorded within the Italian Land Register, were included on F2, a number that, since 2006, observed an annual increase of $25 \%$. Such increments are also a consequence of the tax exemptions reserved for the F2 category, a stimulus to leave irreparable assets to abandonment [24]. Most of the real-estate assets under this context are located in southern Italy (68\%), though there are some clusters placed in alpine or mountainous regions, or in productive districts that suffered a loss of competitiveness due to the economic recession. Regarding this last 
aspect, the presence of abandoned real-estate is intertwined with real-estate market conditions, since, in places where the potential returns upon positional land-rent are sufficient to stimulate renewal investments, decommissioned real-estate assets are subject to regenerative interventions to make use of the built-potential. However, in areas with a limited real-estate market due to a stagnated local economy and depopulation (what we call an area in contraction), not only will regeneration of decommissioned real-estate assets not occur, but the state of decay will also create conditions for the depreciation of the surrounding positional land-rents. Noticeable effects have been verified in the U.S. cases, with specific reference to the American Rust Belt, where the urban demolition policy has been predominant in the past 40 years [10], as well as to the urban area of Cleveland, where local and federal resources have been invested in the demolition of blight structures between 2009 and 2013 [15]. In those contexts, regeneration policies-public or private-have a weak economic foundation and manifest limited efficiency when applied. With these aspects in mind, the absence of a reuse perspective for a medium-term period has recently prompted a debate about possible governance policies that focus on a programmed transition through demolition [25], which makes evident the demands for an alternative approach to the usual regeneration programs. In comparison to cases depicted in the literature, where US and German cases are prevalent $[10,26,27]$, the Italian cases exhibit significant distinctions regarding the reasons that lead to decommissioning, such as the real-estate's physical characteristics, local economic conditions, and the very social structure which perceives housing as a long-term value asset. These differences, as will be demonstrated, strongly affect the strategies, practices, and economic demands of decommissioning policies [28].

The second group of analyzed real-estate assets includes those that are potentially susceptible to demolition policies and urban subtraction, due to their location in areas vulnerable to environmental risks, such as landslides or flooding. In relation to these cases, up-to-date data on the real-estate assets' condition is available, and highlights the properties' dimensions, quantities, and the costs incurred in the mitigation of the natural disaster. A nationwide map that addresses the landslide risks was created by the Istituto Superiore per la Protezione e la Ricerca Ambientale (ISPRA) from data collected by the responsible district authorities for each Basin, and establishes the degree of risk for each area that has a significative probability of experiencing such events through a classification that ranges from P1-Low risk to P4-Critical Risk. This data covers 59,998.24 km², corresponding to $19.87 \%$ of the entire national territory $\left(302,027.46 \mathrm{~km}^{2}\right)$. The areas categorized under the P3-High and P4-Critical categories of risk amount to $42.37 \%\left(25,423 \mathrm{~km}^{2}\right)$ of the total area under vulnerability conditions, a value that denotes the fragility of the Italian territory to landslides, and compatible with its morphological characteristics (Figure 1) [29]. An analogous assessment, also conducted by ISPRA and based on data from each Basin, refers to the nationwide distribution of areas subject to hydrogeological risks, which establishes three scenarios (P1-Low, P2-Medium, and P3-High), regarding the probability of a flood event. In that case, areas categorized as P1-affected only in cases of major events that have a periodicity that exceeds 200 years-have an overall territorial extension of $46,242.35 \mathrm{~km}^{2}$, equivalent to $15.31 \%$ of the entire national territory. Areas categorized as P3-High Risk, where major flooding events happen within an interval between 20 and 50 years, cover a total of $20,929.46 \mathrm{~km}^{2}-6.92 \%$ of the Italian territory, denoting its high vulnerability to flood events (Figure 1). From the intersection of the map data the with urban settlements in a GIS-based environment, it is possible to assess urbanized areas' susceptibility to environmental risks. In this view, $3282.94 \mathrm{~km}^{2}$ of urban areas, which are equivalent to $22.6 \%$ of the total urbanized area in Italy, are categorized within P1, while the areas in P3 amount to $8.72 \%$ of the total $\left(1264.58 \mathrm{~km}^{2}\right.$ ) (Figure 1) [29]. 


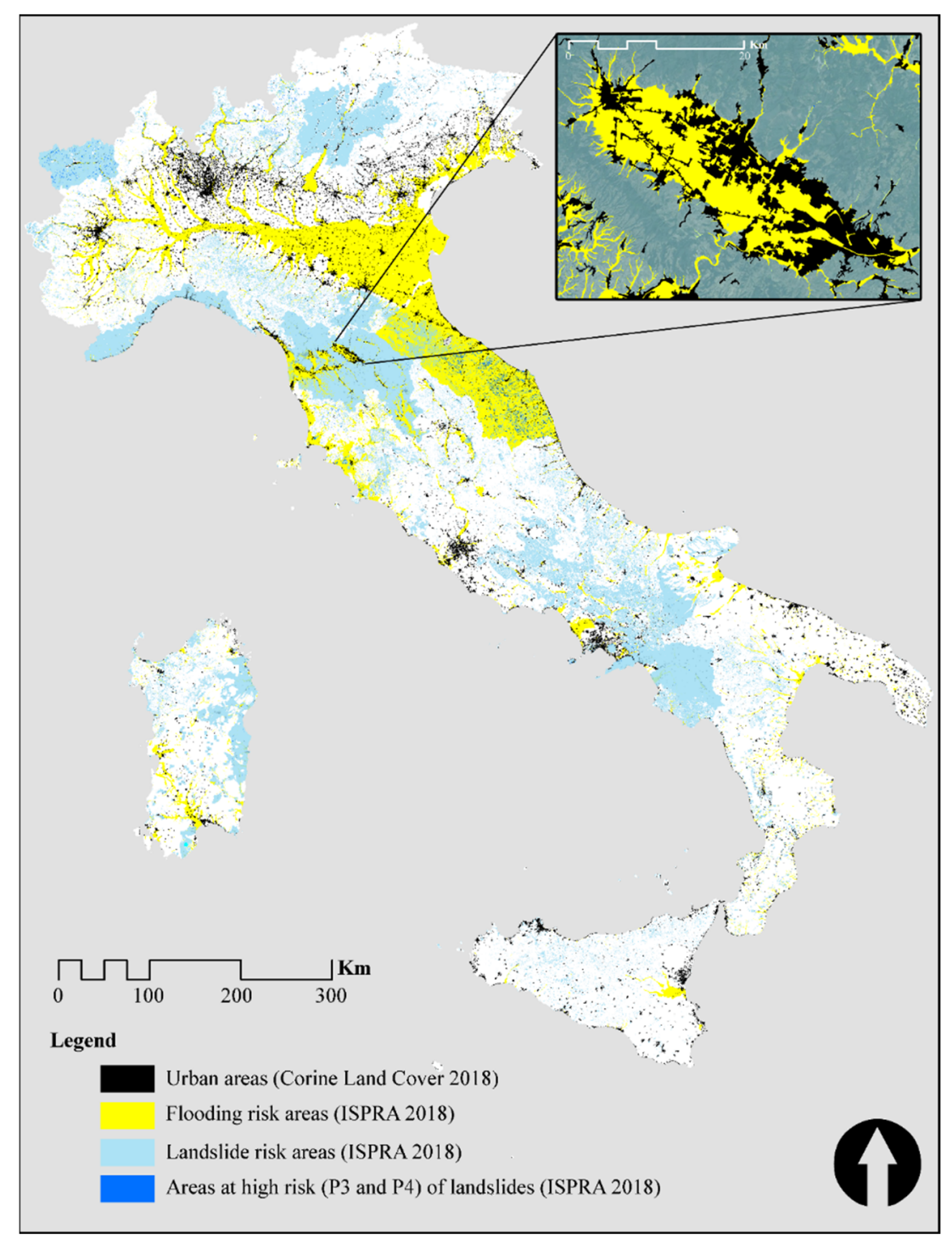

Figure 1. National mosaic of flooding and landslide risk areas-authors' elaboration on ISPRA data [29] —and dislocation of urban areas [30]. The internal box shows a relevant zoomed area in the Tuscany Region.

Regarding the Italian real-estate assets, there are circa 700,000 properties within areas defined as subjected to risk as of 2018. Of these, 227,329 properties-corresponding to 507,895 inhabitants and 31,824 firm local units-were located within areas subject to a very high risk ( $\mathrm{P} 4$ category) of landslides, and 487,895 properties-corresponding to 2,062,475 inhabitants and 197,565 firm local units-were located in areas at high risk of flooding (P3 category) [29]. Considering these numbers, a clear statistical picture emerges, especially in light of several real-estate assets that, despite not being located within areas subject to landslides or flooding, can be affected by them in functional terms. It is possible to analyze the urban land typologies affected by environmental risks in aggregate terms, by using the classification proposed by the Urban Atlas [31] which, in Italy, covers $64,894.09 \mathrm{~km}^{2}-21.49 \%$ of the national territory-and whose maps depict in greater detail the land use disposition in inhabited localities. Using the homologous categories employed in the CORINE mapping (1.1.1; 1.1.2.1; 1.1.2.2; 1.2.1.1) [26] (which covers $7444.18 \mathrm{~km}^{2}$ ) as a reference, urbanized areas categorized as under significant hydrogeologic and/or landslide hazard amount to $1951.82 \mathrm{~km}^{2}$, with a directly exposed number of real-estate assets amounting 600.000 units. In this case, the prevalent typology is made up of industrial and commercial buildings (43.22\%), followed by different forms of urbanization. From 1967 
to 2016, the different categories of risk (seismic and hydrogeological) have created more than 6700 victims [32], with an expenditure allocated to emergency and reconstruction interventions estimated at 240 billion euros in the period 1944-2012, of which 20 billion were spent in the two-year period 2010-2012 alone [33]. The low diffusion of private insurance products related to environmental risks has meant that in Italy, almost all the costs for civil defense and prevention interventions were borne by the State, with a financial commitment of only about 3.5 billion per year of direct costs [34]. The indirect costs, both public and private, should be added to this, and are derived factors such as the closures of production activities and the lack of tax revenue, for example. Considering that these data concern only the main built-up areas of the country, and therefore do not contemplate the widespread urban/built contexts present in peripheral areas which tend to be more exposed to these environmental risks, the condition of the national real-estate assets is rather fragile, and mitigation policies cannot be postponed.

\subsection{Blight Elimination Programs (BEPS)}

The blight elimination program is an initiative subsided by the U.S. Department of the Treasury, aimed at redeveloping urban residential areas by preventing real-estate abandonment and thus oriented to the maintenance of residential property values. The BEP was conceived as a part of the Troubled Asset Relief Program and was a measure devised to counteract the deleterious effects of the U.S. housing crisis due to the unprecedented decline in property values [35]. Evidence of this is the fact that a major part of the funds that feed the program come from the Hardest Hit Fund (HHF), with a total allocation for the BEP alone of $\$ 696,720,274$ as of 30 June 2020, equal to approximately $7.7 \%$ of the globally committed resources [3]. The BEP is based on the idea that declining property values can be countered by removing and greening vacant and blighted residential properties (Stage 1). The program also stipulates that the areas subject to demolition and greening investment must then be maintained for a period of three years, also funded, during which they can be reused or sold for the realization of local development projects (Stage 2).

The program's governance is generally local, as counties and local government units are the entities that can access the funds based on a competitive bidding process. As a result, since 2014, local BEP programs have already been implemented in 19 federal states. Each implementing entity has a defined reference program that is periodically updated on the basis of local competitive calls, through which final beneficiaries are identified. In general lines, the program can be accessed by non-profit organizations and land banks. Local strategies can also involve other local actors, including but not restricted to cooperation between private owners and organizations (i.e., associations of property owners, community development corporations, and economic development entities), since the idea is that these partnerships can facilitate an effective implementation of demolition interventions. Each BEP local program is able to finance the acquisition (if the real-estate assets are not already owned by the applicant) of up to a maximum of $40 \%$ of the total costs and the demolition of abandoned residential properties, as well as the redevelopment of the vacant area-greening —up to a maximum of $\$ 25,000$ USD (Stage 1). Subsequently, the program subsides the maintenance of the redeveloped areas for the next three years, with a maximum amount close to \$2000 USD per year (Stage 2). However, the actual costs of implementation result to average costs-in Stage 1-of around \$10,000 USD (Mississippi Home Corporation, 2017) [3]. An analysis of the results of the first phase of BEP implementation demonstrated that the values of real-estate located within a 500-foot radius from the renovated area had increased by an average of $4.2 \%$, while the values of properties located within a Hardest Hit Fund zone (program area), but beyond the 500-foot radius from where interventions were made, increased their overall value by $13.8 \%$. This is important evidence, as every dollar invested in BEPs has an estimated return of \$4.27 USD in terms of the actual value attributed to nearby properties (home equity value) and \$8.35 in terms of actual value attributed to homes in the entire Hardest Hit Fund zone [28]. 
The case chosen for comparison to the Italian case of Lecce nei Marsi in this paper is the Indiana's (U.S.) Hardest Hit Fund blight elimination program, which gave the 92 counties in this State the opportunity to access the subsides for the BEP program, achieving significant results in multiple declining residential areas [36].

\subsection{Flood Buyout Programs (FBPS)}

Flood buyout programs consist of federal initiatives aimed at the acquisition and demolition of private residential properties located in flood hazard areas. In the U.S., these programs are subsidized by the Federal Emergency Management Agency and co-funded by state and local funds [11]. Over the past 30 years, FBPs have become a well-established tool for medium and long-term risk mitigation policies in the United States, with 25 programs completed and in progress, and over 40,000 structures demolished since the 1980s [27,37]. The idea is founded on the recognition that flood damage to private properties, which is mostly paid for with public funds, often exceeds the costs of demolition and rebuilding the real-estate asset in safe areas, therefore justifying the economic effort of relocation. Studies conducted by the U.S. Federal Emergency Management and the National Institute of Building Sciences state that for every dollar spent in FBP initiatives, approximately $\$ 4.00$ USD are saved in costs for compensation or mitigation of future damage [38]. Independent studies, while employing different quantification and estimation methods, also confirm the cost-effectiveness of this policy in protecting the public and reducing damage to structures [26].

FBPs can be activated by the federal government, through the Federal Emergency Management Agency immediately after the occurrence of a flood event recognized as a critical disaster. Since programs are active over a medium to long-term period, they must therefore be considered reactive rather than proactive programs [39]. Following this step, the implementation mechanism involves the identification of all damaged realestate assets and the assessment of those deemed most at risk, for which federal funds are made available. The buyout process is voluntary, and the property owners can choose whether to sell their property to the public entities in charge of the program or to remain in possession of it. In case of adhesion, the buyout value is the one estimated before the damages produced by the flood, thus, differing based on the type, location, and state of preservation of the real-estate assets. Acquired properties are demolished and the freed areas are renaturalized or used as public green spaces compatible with the environmental risks. In this aspect, the mitigation of risk through FBPs also occurs in the medium and long-term, by preventing the recurrence of damage to real-estate assets, hence mitigating the negative externalities manifested by the construction within flood-susceptible areas.

The chosen case for enacting comparisons with the Italian case-study of Moncalieri is the flood buyout program of Nashville, Tennessee, which was implemented after extraordinary rainfalls in Davidson County during May 2010, which caused the Cumberland River and its tributaries to flood and resulted in 21 fatalities, alongside more than \$2 Billion USD in damage to over 11,000 structures. This flooding affected large areas in the Davidson County lowlands, concentrating damage in the section where the Cumberland River flows through the city of Nashville. Numerous residential, manufacturing, and public services developments are located on the urbanized riverbanks, such as the Nissan Stadium, which is placed on an area of about 13 square miles at risk of flooding, with return times of 100 and 500 years. The overflow of three tributaries on the left bank of the river, which are also greatly anthropized, has caused damage in several areas of the city that are distant from the Cumberland River. The program, administered by the Federal Emergency Management Agency and the Stormwater Division of Metro Water Services in Nashville, initially identified 305 properties that were potentially eligible for acquisition because they fell within the flood-affected areas and those with return times greater than 100 years. Of these, only 249 expressed interest in joining by participating in a 4-meeting round to learn about and define the program. From 2010 to 2016, real-estate assets amounting to a total value of approximately $\$ 34.2$ Million USD were acquired, ranging in value from 
$\$ 11,000$ USD to $\$ 480,000$ USD, and with an average acquisition cost of $\$ 145,000$ USD [26]. The acquired housing stock was predominantly made of mono-familiar, single-story, and isolated real-estate, with an average built area of approximately $150 \mathrm{~m}^{2}$, with lots varying in size and placed in different neighborhoods. The prevalent building typology is comprised of load-bearing structures with foundations in wood and reinforced concrete.

\section{A Simulation in the Italian Scenario}

Simulations of the previously discussed U.S. demolition program's application are made for two Italian cases that exhibit a similar condition of real-estate asset decommissioning or built-structures under environmental risks. Above all, the chosen cases represent phenomena that are quite present in Italy: real-estate abandonment in the municipalities' village areas, and the management of real-estate assets in areas subject to high hydrogeological risks.

The case studies were selected according to two key criteria: (i) The representativeness of a large part of Italian heritage which is in an unsustainable condition for the reuse of the existing buildings; (ii) The representativeness of the specific risk conditions regarding flood buyout programs, which in Italy, moreover, are particularly fitting. In selecting of cases, the availability of data stored in publicly accessible repositories controlled by public authorities was also taken into account.

The selected case studies, while recalling the fundamental conditions for the simulation of the aforementioned US programs, represent the scenarios most likely to be in line with the implementation of demolition policies within the Italian context. Therefore, they were selected to pursue the primary objective of this work, which is to propose a preliminary assessment of the applicability of these demolition policies to the "case of Italy", without wishing in any way to propose a comparison between Italy and the US.

The flood buyout program is simulated in the neighborhood of Tagliaferro-Moncalieri municipality - part of Torino's urban boundaries (Piemont Region), an area that suffered a severe flood event in 2016 due to the overflow of the Chisola River, a tributary of the Po River. The blight elimination program is simulated within the historical site of Lecce nei Marsi, a municipality in the L'Aquila province (Abruzzo Region), which is characterized by the massive presence of decommissioned and abandoned real-estate assets without valuable historical heritage features.

Simulations involved two sets of analyses: (i) The programs' economic assessment regarding demolition costs and overall built-structures' characteristics; (ii) The related urban planning and administrative implications.

Each simulation has been made by implementing the following methodology:

- The identification of the study area by defining a bound that isolates a cluster of buildings. For the definition of such a bound, in the BEP case, the homogeneity of the assets and the system of roads demarking the lots is taken into account. In the case of the FBP, the limit of the areas effectively subject to a major flooding event is mainly taken into account, in order to carry out a meaningful simulation in realistic conditions.

- The punctual identification of the real-estate assets within the study area, leading to the association of a unique identifier with each real-estate unit;

- The dimensional quantification of each building in the study area, leading to a reliable estimation of the constructed volume;

- The estimation of the economic costs of demolition for each building;

- The estimation of the total economic cost of the demolition of each program;

- An evaluation of the urban-administrative procedures needed to implement the demolitions.

The identification of real-estate assets subject to removal was conducted in a GISbased environment, using the Google Maps [40] and Google Earth [41] cartographic bases, associated to the ISPRA hydrogeological risk map [42] in the case of areas subjected to hydrogeological risk. From these maps, the total built area is drawn, as well as the approximate surface area of the lots where the real-estate assets are placed. The data was 
used to elaborate a dimensional quantification of the built-structure and to estimate the economic costs of demolition.

\subsection{Demolition of the Decomissioned Real-Estate Assets: The Case of Lecce nei Marsi (L'Aquila)}

The simulation for the blight elimination program was performed in the Lecce nei Marsi municipality, a small urban centre with 1500 inhabitants located in the margins of the Fucino plains in the Abruzzo Region, in the province of L'Aquila (Figure 2).

The decommissioned real-estate assets' presence in this area can be traced to two causes: the first, and most important, was the 1915 Marisca earthquake which affected Lecce nei Marsi, causing 30,519 deaths, extensive property damage, and a subsequent populational displacement from the hill-base settlements towards the reclaimed plains of Fucino Lake. The second was the Italian economic development process in the postwar period (1950-1990), which polarized industry in large metropolitan areas and caused internal migrations that created several territorial disparities in terms of services and infrastructure. Like other settlements in the area, Lecce nei Marsi possess a duplicated inhabited centre, due to the abandonment of the hillside villages and the reconstruction in the valley areas. In this context of economic exposure and the absence of tourist flows, few incentives towards renewal exist. Hence, the abandoned real-estate assets are left in a condition of decay which is critical in terms of public safety and landscape quality.

The Lecce nei Marsi decommissioned real-estate assets assessed in the simulation are located in a rather isolated urban area, accessible through a single street. Although the area is integrated into the urban fabric, several buildings are isolated in the mountainous landscape (number 2 picture in Figure 2, LNM6 and LNM 12). Built-structures are similar in construction technique-stone masonry with wooden floors-and are mostly set on the street front. The area is characterized by the coexistence of buildings with different states of preservation: those still in use or decommissioned yet structurally intact (LNM 3, LNM5), and those in a state of decay, without roofs and floors (LNM6, LNM8,). All lots are privately owned.

The real-estate assets identified as to-be demolished consist of 17 buildings, all in a state of underuse or complete abandonment (number 2 picture in Figure 2), and dating back to the second half of the 19th century and early 20th century. Their dimensional characteristics are displayed in Tables 1 and 2. 

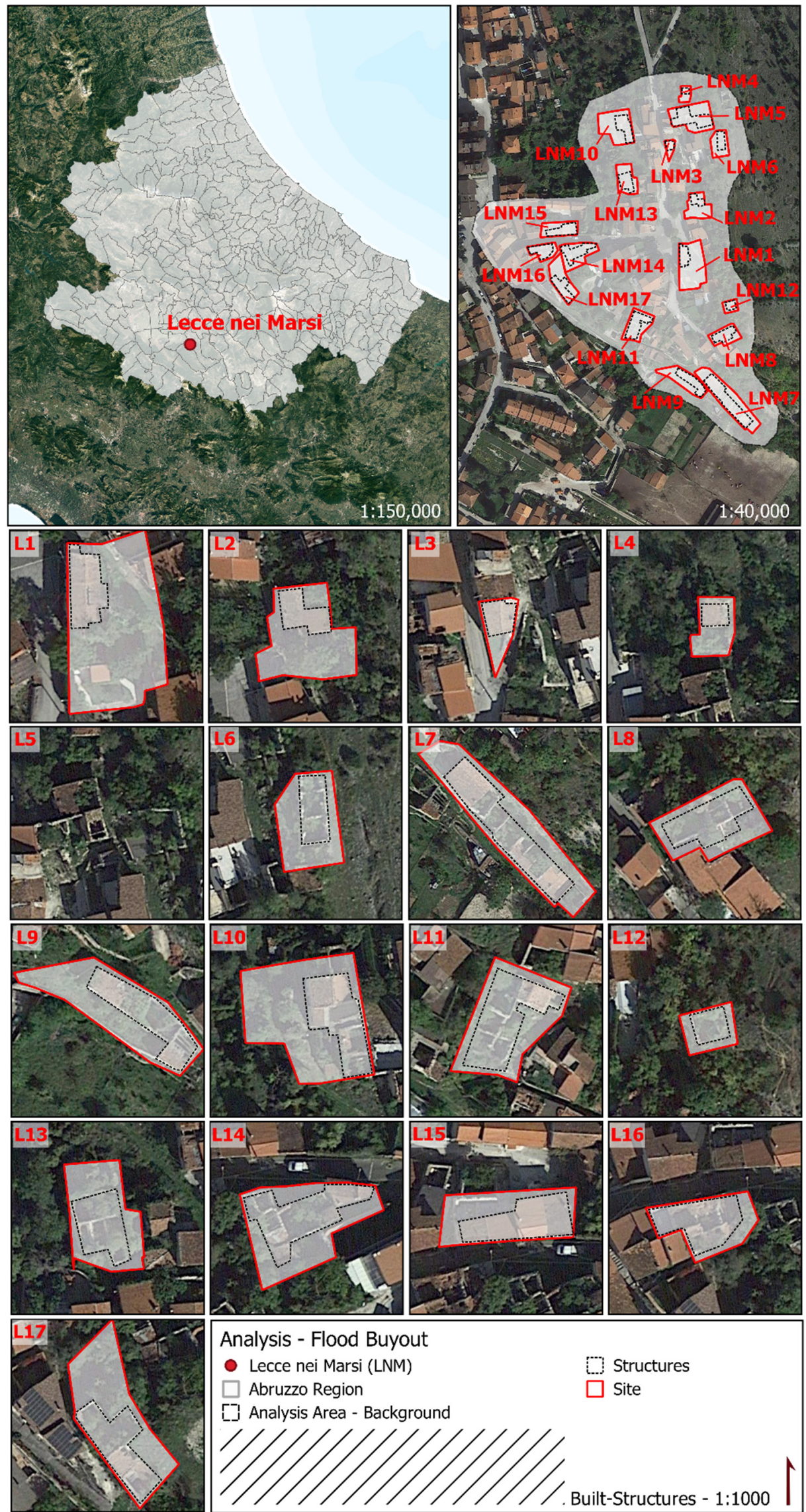

Figure 2. Territorial localization of the Lecce nei Marsi (LNM) blight elimination program simulation. 
Table 1. Lecce nei Marsi (LNM) buildings' dimensional characteristics.

\begin{tabular}{|c|c|c|c|c|c|}
\hline A & B & $\mathrm{C}$ & D & $\mathbf{E}$ & F \\
\hline ID & $\begin{array}{c}\text { Lot Surface } \\
\qquad\left(\mathrm{m}^{2}\right)\end{array}$ & $\begin{array}{c}\text { Building } \\
\text { Surface }\left(\mathrm{m}^{2}\right)\end{array}$ & $\begin{array}{c}\text { Building } \\
\text { Perimeter }(\mathrm{m})\end{array}$ & $\begin{array}{l}\text { Number of } \\
\text { Floors }\end{array}$ & $\begin{array}{c}\text { Floor Average } \\
\text { Height (m) }\end{array}$ \\
\hline LNM1 & 109.53 & 108.32 & 50.41 & 2 & 3.00 \\
\hline LNM2 & 79.75 & 67.55 & 40.18 & 2 & 3.00 \\
\hline LNM3 & 42.17 & 42.47 & 26.43 & 2 & 3.00 \\
\hline LNM4 & 42.34 & 26.31 & 20.64 & 1 & 3.50 \\
\hline LNM5 & 103.18 & 287.45 & 94.55 & 2 & 3.00 \\
\hline LNM6 & 62.31 & 82.13 & 39.99 & 2 & 3.00 \\
\hline LNM7 & 147.17 & 399.45 & 116.25 & 2 & 3.00 \\
\hline LNM9 & 97.27 & 164.18 & 69.76 & 2 & 3.00 \\
\hline LNM10 & 98.69 & 180.42 & 65.42 & 2 & 3.00 \\
\hline LNM11 & 81.51 & 206.7 & 76.19 & 2 & 3.00 \\
\hline LNM12 & 39.43 & 47.42 & 27.58 & 2 & 3.00 \\
\hline LNM13 & 78.21 & 128.36 & 49.49 & 2 & 3.00 \\
\hline LNM14 & 89.27 & 202.33 & 81.48 & 1 & 3.5 \\
\hline LNM15 & 77.57 & 159.85 & 61.98 & 1 & 3.5 \\
\hline LNM16 & 64.71 & 145.29 & 54.80 & 1 & 3.5 \\
\hline LNM17 & 95.36 & 156.63 & 66.74 & 2 & 3 \\
\hline
\end{tabular}

Table 2. Lecce nei Marsi (LNM) buildings' and ruins' dimensional quantification.

\begin{tabular}{cccccc}
\hline A & G & \multicolumn{3}{c}{ H } \\
\hline \multirow{2}{*}{ ID } & Volume $\mathbf{( m}^{\mathbf{3}} \mathbf{)}$ & \multicolumn{3}{c}{ Ruins Volume $\mathbf{( m}^{\mathbf{3}} \mathbf{)}$} \\
\cline { 2 - 6 } & [Table $\mathbf{1}-\mathbf{C} \times \mathbf{E} \times \mathbf{F}]$ & Shell & Slabs & Partition Walls & Total \\
\hline LNM1 & 649.92 & 20.16 & 67.99 & 32.50 & 120.65 \\
LNM2 & 405.30 & 16.07 & 35.41 & 20.27 & 71.74 \\
LNM3 & 254.82 & 10.57 & 21.33 & 12.74 & 44.64 \\
LNM4 & 92.09 & 8.26 & 18.05 & 9.21 & 35.52 \\
LNM5 & 1724.70 & 37.82 & 211.81 & 86.24 & 335.87 \\
LNM6 & 492.78 & 16.00 & 50.14 & 24.64 & 90.77 \\
LNM7 & 2396.70 & 46.50 & 306.45 & 119.84 & 472.79 \\
LNM9 & 985.08 & 27.90 & 108.37 & 49.25 & 185.53 \\
LNM10 & 1082.52 & 26.17 & 128.08 & 54.13 & 208.38 \\
LNM11 & 1240.20 & 30.48 & 145.75 & 62.01 & 238.23 \\
LNM12 & 284.52 & 11.03 & 25.36 & 14.23 & 50.61 \\
LNM13 & 770.16 & 19.80 & 88.77 & 38.51 & 147.07 \\
LNM14 & 708.16 & 32.59 & 169.74 & 70.82 & 273.15 \\
LNM15 & 559.48 & 24.79 & 135.06 & 55.95 & 215.80 \\
LNM16 & 508.52 & 21.92 & 123.37 & 50.85 & 196.14 \\
LNM17 & 939.78 & 26.70 & 103.24 & 46.99 & 176.92 \\
\hline
\end{tabular}

For the identified buildings, the simulation foresees the complete demolition, the renaturalization, and the securing of the areas. As in the U.S. blight elimination program, the direct costs of the program will be the only costs related to the demolition, assuming zero real-estate value, which is considered a foundational assumption of the feasibility of demolition policies. Therefore, total removal costs are estimated on a semi-parametric basis through the determination of costs as a sum of demolition costs, including transportation, landfill charges (disposal costs) - based on the total demolished volume (Table 2) - and the renewal and renaturation costs for each lot:

$$
K_{b}=K_{d}+K_{s}+K_{r n}
$$

where:

$K_{b}$ equals the total removal costs; 
$K_{d}$ equals the demolition costs;

$K_{s}$ equals the disposal costs;

$K_{r n}$ equals the lot renewal and renaturalizing costs.

The costs of demolition $\left(K_{d}\right)$ are related to global costs referring to labor costs, the handling of materials, and those of disposal $\left(K_{s}\right)$. Transport and landfill charges are parametric, and obtained from the price list of the Abruzzo Region for 2021 with reference to the total demolition of masonry buildings (item E.01.50.10.a and E.01.210.20.n). The costs of renaturalization $\left(K_{r n}\right)$ refer to the lot cleaning processes and the planting of native vegetation, and are taken from an analytical study previously conducted on the same geographical area [14]. The total costs breakdown for the Lecce nei Marsi blight elimination program can be observed in Table 3.

Table 3. Lecce nei Marsi (LNM) blight elimination program costs estimation.

\begin{tabular}{|c|c|c|c|c|c|c|c|c|}
\hline \multirow[b]{3}{*}{ ID } & \multicolumn{2}{|c|}{$\mathbf{I}$} & \multicolumn{3}{|c|}{$\mathbf{J}$} & \multicolumn{2}{|c|}{$\mathbf{K}$} & \multirow{3}{*}{$\begin{array}{c}\mathrm{L} \\
{[\mathrm{I}+\mathrm{J}+\mathrm{K}]} \\
\begin{array}{c}\text { Total Cost } \\
(€)\end{array}\end{array}$} \\
\hline & \multicolumn{2}{|c|}{ Demolition Cost $(€)$} & \multicolumn{3}{|c|}{ Waste Disposal Cost $(€)$} & \multicolumn{2}{|c|}{ Greening Cost $(€)$} & \\
\hline & $\begin{array}{l}\text { U. Cost } \\
\left(€ / \mathrm{m}^{3}\right)\end{array}$ & $\begin{array}{c}\text { Total Cost } \\
(€)\end{array}$ & $\begin{array}{l}\text { Waste } \\
\left(t / m^{3}\right)\end{array}$ & $\begin{array}{c}\text { U. Cost } \\
(€ / \text { t. })\end{array}$ & $\begin{array}{l}\text { Total Cost } \\
(€)\end{array}$ & $\begin{array}{l}\text { U. Cost } \\
\left(€ / \mathrm{m}^{3}\right)\end{array}$ & $\begin{array}{c}\text { Total Cost } \\
(€)\end{array}$ & \\
\hline LNM1 & 11.86 & 7708.05 & 1.60 & 18.99 & 3665.89 & 25.93 & 2840.11 & $14,214.05$ \\
\hline LNM2 & 11.86 & 4806.86 & 1.60 & 18.99 & 2179.84 & 25.93 & 2067.92 & 9054.61 \\
\hline LNM3 & 11.86 & 3022.17 & 1.60 & 18.99 & 1356.31 & 25.93 & 1093.47 & 5471.94 \\
\hline LNM4 & 11.86 & 1092.13 & 1.60 & 18.99 & 1079.19 & 25.93 & 1097.88 & 3269.20 \\
\hline LNM5 & 11.86 & $20,454.94$ & 1.60 & 18.99 & $10,204.92$ & 25.93 & 2675.46 & $33,335.32$ \\
\hline LNM6 & 11.86 & 5844.37 & 1.60 & 18.99 & 2758.05 & 25.93 & 1615.70 & $10,218.12$ \\
\hline LNM7 & 11.86 & $28,424.86$ & 1.60 & 18.99 & $14,365.10$ & 25.93 & 3816.12 & $46,606.08$ \\
\hline LNM9 & 11.86 & $11,683.05$ & 1.60 & 18.99 & 5637.14 & 25.93 & 2522.21 & $19,842.40$ \\
\hline LNM10 & 11.86 & $12,838.69$ & 1.60 & 18.99 & 6331.36 & 25.93 & 2559.03 & $21,729.08$ \\
\hline LNM11 & 11.86 & $14,708.77$ & 1.60 & 18.99 & 7238.50 & 25.93 & 2113.55 & $24,060.83$ \\
\hline LNM12 & 11.86 & 3374.41 & 1.60 & 18.99 & 1537.86 & 25.93 & 1022.42 & 5934.68 \\
\hline LNM13 & 11.86 & 9134.10 & 1.60 & 18.99 & 4468.64 & 25.93 & 2027.99 & $15,630.72$ \\
\hline LNM14 & 11.86 & 8398.72 & 1.60 & 18.99 & 8299.25 & 25.93 & 2314.77 & $19,012.74$ \\
\hline LNM15 & 11.86 & 6635.37 & 1.60 & 18.99 & 6556.79 & 25.93 & 2011.39 & $15,203.55$ \\
\hline LNM16 & 11.86 & 6030.99 & 1.60 & 18.99 & 5959.56 & 25.93 & 1677.93 & $13,668.48$ \\
\hline LNM17 & 11.86 & $11,145.79$ & 1.60 & 18.99 & 5375.63 & 25.93 & 2472.68 & $18,994.10$ \\
\hline
\end{tabular}

The estimated demolition, disposal, and greening costs $(\mathrm{I}+\mathrm{J}+\mathrm{K})$ of the Lecce nei Marsi blight elimination program total 276,245.92 Euros, with significative differentiations between built-structures due to their state of preservation and the size of the sites. Average costs are equal to 17,265.37 Euros with an average incidence of disposal costs of $31.9 \%$, and greening costs of $12.28 \%$, which are eliminated if the real-estate asset is recovered instead of demolished. Despite differences in preservation as well as building and construction typologies, the costs of demolition are comparable to the maximum costs provided in the Richmond blight elimination program. In relation to the financial capacity of the municipality, the cost of the removal program applied to the buildings in the case study would represent $3 \%$ of the total expenses incurred by the administration (9,088,228 Euros) and $43 \%$ of the expenses incurred for the protection of the territory and the environment $(635,157$ Euros) [43]. The total cost of the program should be spread over several fiscal exercises, since the program observes horizons between 3 and 5 years, thus significantly reducing the economic weight in relation to the municipal financial capacity.

\subsection{Demolition of Real-Estate Assets under Risk: The Case of Moncalieri (Torino)}

The simulation regarding a flood buyout program for an Italian case encompassed Tagliaferro, a small neighborhood of the municipality Moncalieri, placed in the Torino's metropolitan region (Figure 3). 


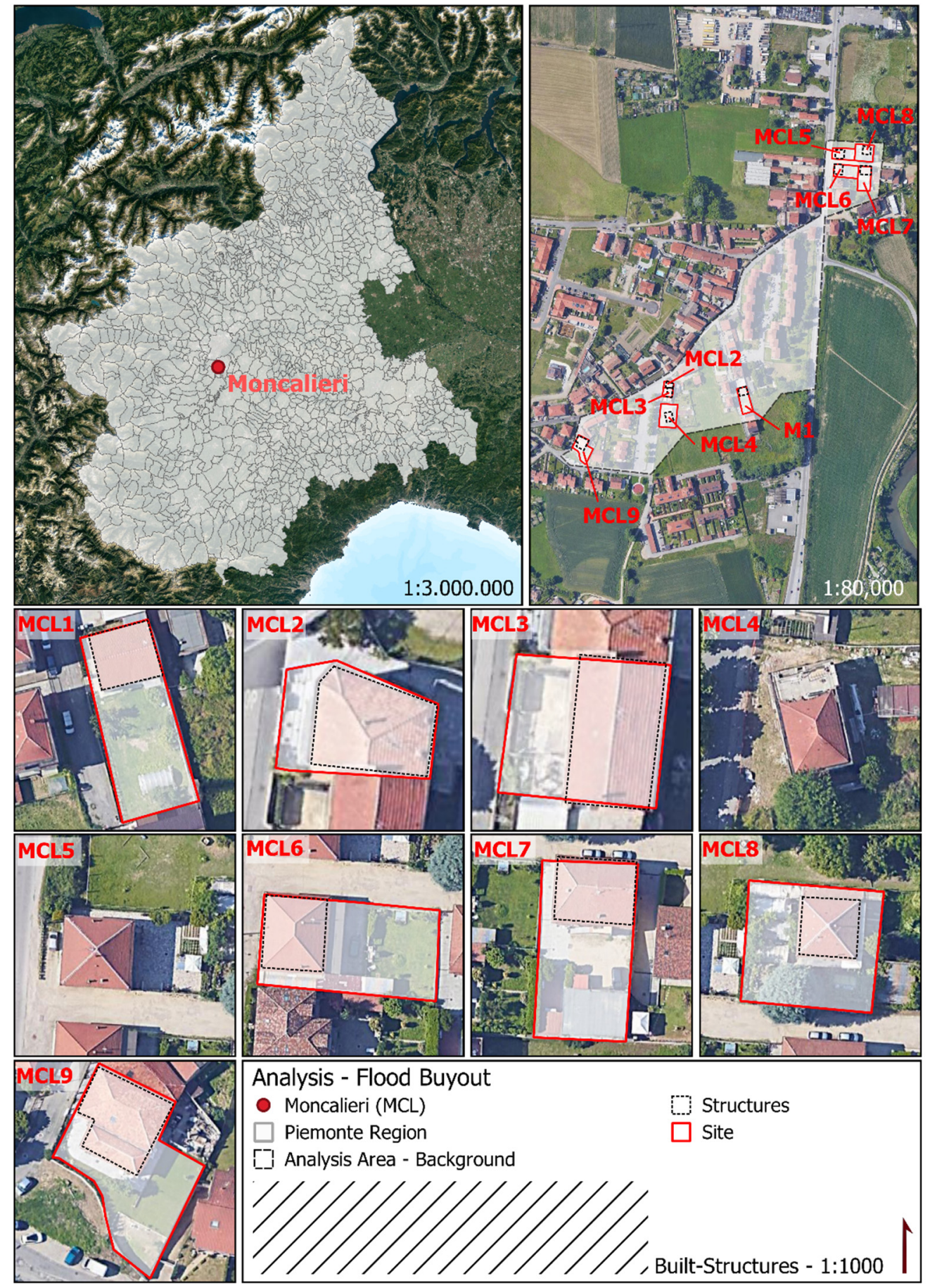

Figure 3. Territorial localization of the Moncalieri $(M C L)$ flood buyout program simulation.

In November 2016, the area was affected by the overflow of the Chisola river, which caused a total of 13,974,741.89 Euros (1318 claims) in real-estate damage and a total of 49,307,165.28 Euros (260 claims) of damage to productive assets. The most affected residential district was Tetti Piatti (where the real-estate areas considered in the simulation are placed), with damage to the ground floors of the houses and numerous movable properties. The real-estate affected by water damage are rather heterogeneous in nature, being composed of social housing, twin-homes, or semi-detached homes, mostly with two-stories and terraces (number 2 picture in Figure 3). The buildings are mostly made with reinforced concrete structures and brick infills, with the exception of some former agricultural buildings made with masonry load-bearing structures. Social housings are located near to the 
river, composed of a series of five-story buildings. The real-estate considered for buyout under the program are located in the most affected areas. Within these areas, buildings with lesser value or a greater degree of obsolescence were chosen, for which it is reasonable to assume a greater interest by the owners towards a possible acquisition. The real-estate assets considered for the Moncalieri flood buyout program consist of nine buildings dating to the second half of the 20th century, whose dimensional characteristics are displayed in Tables 4 and 5 .

Table 4. Moncalieri (MCL) buildings' dimensional characteristics.

\begin{tabular}{|c|c|c|c|c|c|}
\hline A & B & C & D & E & F \\
\hline ID & $\begin{array}{c}\text { Lot Surface } \\
\qquad\left(\mathrm{m}^{2}\right)\end{array}$ & $\begin{array}{c}\text { Building } \\
\text { Surface }\left(\mathrm{m}^{2}\right)\end{array}$ & $\begin{array}{c}\text { Building } \\
\text { Perimeter (m) }\end{array}$ & $\begin{array}{c}\text { Number of } \\
\text { Floors }\end{array}$ & $\begin{array}{c}\text { Floor Average } \\
\text { Height (m) }\end{array}$ \\
\hline MCL1 & 478.86 & 118.24 & 43.55 & 2 & 3.60 \\
\hline MCL2 & 105.77 & 71.40 & 33.67 & 2 & 3.60 \\
\hline MCL3 & 155.06 & 87.98 & 38.97 & 2 & 3.25 \\
\hline MCL4 & 698.32 & 115.70 & 43.42 & 2 & 3.10 \\
\hline MCL5 & 458.98 & 135.55 & 46.57 & 2 & 3.40 \\
\hline MCL6 & 544.76 & 150.00 & 49.15 & 2 & 3.40 \\
\hline MCL7 & 562.47 & 168.19 & 52.21 & 2 & 3.40 \\
\hline MCL8 & 546.45 & 112.47 & 42.42 & 2 & 3.40 \\
\hline MCL9 & 554.99 & 200.32 & 59.44 & 2 & 3.40 \\
\hline
\end{tabular}

Table 5. Moncalieri (MCL) buildings' and ruins' dimensional quantification.

\begin{tabular}{cccccc}
\hline A & G & \multicolumn{3}{c}{ H } \\
\hline \multirow{2}{*}{ ID } & Volume $\left(\mathbf{m}^{\mathbf{3}}\right)$ & \multicolumn{3}{c}{ Ruins Volume $\mathbf{( m}^{\mathbf{3}} \mathbf{)}$} \\
\cline { 2 - 6 } & [Table $1-\mathbf{C} \times \mathbf{E} \times \mathbf{F}]$ & Shell & Slabs & Partition Walls & Total \\
\hline MCL1 & 851.33 & 17.42 & 83.40 & 42.57 & 143.39 \\
MCL2 & 514.08 & 13.47 & 44.46 & 25.70 & 83.64 \\
MCL3 & 571.87 & 15.59 & 56.80 & 28.59 & 100.99 \\
MCL4 & 717.34 & 17.37 & 80.96 & 35.87 & 134.20 \\
MCL5 & 921.74 & 18.63 & 98.29 & 46.09 & 163.01 \\
MCL6 & 1020.00 & 19.66 & 110.68 & 51.00 & 181.34 \\
MCL7 & 1143.69 & 20.88 & 126.42 & 57.18 & 204.49 \\
MCL8 & 764.80 & 16.97 & 78.53 & 38.24 & 133.74 \\
MCL9 & 1362.18 & 23.78 & 152.77 & 68.11 & 244.65 \\
\hline
\end{tabular}

The costs incurred in this case are those related to the acquisition of the building, its demolition, and the cost of the renaturalization of the soil. The overall cost of removal is also determined by evaluating the size of the lot, the buildings, and the volume of the ruins (shell, slabs, and partition walls). The acquisition cost is derived from data from the Real Estate Market Observatory (OMI) [44] of the Internal Revenue Service. The area examined falls within zone D2, with sales values for the selected typologies ranging between 1100 and 1650 euro/sqm. The market value has been attributed on the basis of the typological and conservation characteristics, and verified with a direct survey of real-estate brokers in the area. The costs to be incurred also include the cost of the renaturalization of the soil.

$$
K_{b}=V_{r}+K_{d}+K_{s}+K_{r n}
$$

where:

$K_{b}$ equals the total removal costs;

$V_{r}$ equals the real-estate value/acquisition costs;

$K_{d}$ equals the demolition costs;

$K_{s}$ equals the disposal costs;

$K_{r m}$ equals the lot renewal and renaturalization costs. 
In on the above equation, the demolition $\left(K_{d}\right)$, disposal $\left(K_{s}\right)$, and renaturalization $\left(K_{r n}\right)$ costs refer to the same parameters as in BEP, added to the costs referring to the real-estate asset acquisition.

The total cost of the flood buyout program is estimated to be around 3,461,864.91 Euros, are displayed in Tables 6 and 7. When compared to the blight elimination program, the differences in costs reside in the property acquisition, which in the flood buyout program is the highest cost component $(92.14 \%$ of the total). The estimated property values are determined through the average OMI (Osservatorio Mercato Immobiliare) values surveyed for the region and equal 3,189,587.50 Euros in total. The average cost of the program is significantly higher than that of Nashville due both to the higher demolition expenses and, above all, to the acquisition costs of the properties. Considering the financial capacity of the Moncalieri municipality, the removal of the nine buildings considered in the case study would comprise approximately $3.61 \%$ of the total yearly budget (95,822,497.00 Euros) and $12.33 \%$ of the expenditures allocated to sustainable development and land and environmental protection $(28,067,172.00$ Euros $)$.

Table 6. Moncalieri (MCL) flood buyout program demolition, disposal, and greening cost estimations.

\begin{tabular}{|c|c|c|c|c|c|c|c|c|}
\hline \multirow[b]{3}{*}{ ID } & \multicolumn{2}{|c|}{$\mathbf{I}$} & \multicolumn{3}{|c|}{$\mathbf{J}$} & \multicolumn{2}{|c|}{$\mathbf{K}$} & \multirow{3}{*}{ 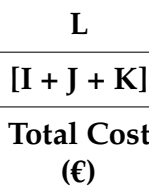 } \\
\hline & \multicolumn{2}{|c|}{ Demolition Cost $(€)$} & \multicolumn{3}{|c|}{ Waste Disposal Cost (€) } & \multicolumn{2}{|c|}{ Greening Cost $(€)$} & \\
\hline & $\begin{array}{l}\text { U. Cost } \\
\left(€ / \mathrm{m}^{3}\right)\end{array}$ & $\begin{array}{l}\text { Total Cost } \\
(€)\end{array}$ & $\begin{array}{l}\text { Waste } \\
\left(\mathrm{t} / \mathrm{m}^{3}\right)\end{array}$ & $\begin{array}{c}\text { U. Cost } \\
(€ / t .)\end{array}$ & $\begin{array}{l}\text { Total Cost } \\
(€)\end{array}$ & $\begin{array}{l}\text { U. Cost } \\
\left(€ / \mathrm{m}^{3}\right)\end{array}$ & $\begin{array}{c}\text { Total Cost } \\
\text { (€) }\end{array}$ & \\
\hline MCL1 & 12.6 & $10,726.73$ & 1.6 & 30 & 6882.55 & 25.93 & $12,416.84$ & $30,026.12$ \\
\hline MCL2 & 12.6 & 6477.41 & 1.6 & 30 & 4014.53 & 25.93 & 2742.62 & $13,234.55$ \\
\hline MCL3 & 12.6 & 7205.56 & 1.6 & 30 & 4847.30 & 25.93 & 4020.71 & $16,073.57$ \\
\hline MCL4 & 12.6 & 9038.48 & 1.6 & 30 & 6441.55 & 25.93 & $18,107.44$ & $33,587.47$ \\
\hline MCL5 & 12.6 & $11,613.92$ & 1.6 & 30 & 7824.43 & 25.93 & $11,901.35$ & $31,339.71$ \\
\hline MCL6 & 12.6 & $12,852.00$ & 1.6 & 30 & 8704.32 & 25.93 & $14,125.63$ & $35,681.95$ \\
\hline MCL7 & 12.6 & $14,410.52$ & 1.6 & 30 & 9815.55 & 25.93 & $14,584.85$ & $38,810.92$ \\
\hline MCL8 & 12.6 & 9636.43 & 1.6 & 30 & 6419.61 & 25.93 & $14,169.45$ & $30,225.48$ \\
\hline MCL9 & 12.6 & $17,163.42$ & 1.6 & 30 & $11,743.33$ & 25.93 & $14,390.89$ & $43,297.64$ \\
\hline
\end{tabular}

Table 7. Moncalieri (MCL) flood buyout program acquisition cost estimations based on local OMI values.

\begin{tabular}{|c|c|c|c|c|c|c|c|c|}
\hline \multirow[b]{3}{*}{ ID } & \multirow{3}{*}{$\begin{array}{l}\text { Floor Surface } \\
\qquad\left(\mathrm{m}^{2}\right)\end{array}$} & \multirow{3}{*}{$\begin{array}{l}\text { Total Building } \\
\text { Surface }\left(\mathrm{m}^{2}\right)\end{array}$} & \multicolumn{3}{|c|}{$\mathbf{O}$} & \multicolumn{3}{|c|}{$\mathbf{P}$} \\
\hline & & & \multicolumn{3}{|c|}{ OMI Unitary House Price $\left(€ / \mathrm{m}^{2}\right)$} & \multicolumn{3}{|c|}{ House Price $(€)$} \\
\hline & & & $\underset{(€)}{\operatorname{Min}}$ & $\begin{array}{c}\operatorname{Max} \\
(€)\end{array}$ & $\begin{array}{c}\text { Mean } \\
(€)\end{array}$ & $\underset{(€)}{\operatorname{Min}}$ & $\begin{array}{c}\operatorname{Max} \\
(€)\end{array}$ & $\begin{array}{c}\text { Estimated } \\
\text { Value }(€)\end{array}$ \\
\hline MCL1 & 118.24 & 236.48 & 1100 & 1650 & 1375 & $260,128.00$ & $390,192.00$ & $325,160.00$ \\
\hline MCL2 & 71.4 & 142.8 & 1100 & 1650 & 1375 & $157,080.00$ & $235,620.00$ & $196,350.00$ \\
\hline MCL3 & 87.98 & 175.96 & 1100 & 1650 & 1375 & $193,556.00$ & $290,334.00$ & $241,945.00$ \\
\hline MCL4 & 115.7 & 231.4 & 1100 & 1650 & 1375 & $254,540.00$ & $381,810.00$ & $318,175.00$ \\
\hline MCL5 & 135.55 & 271.1 & 1100 & 1650 & 1375 & $298,210.00$ & $447,315.00$ & $372,762.50$ \\
\hline MCL6 & 150 & 300 & 1100 & 1650 & 1375 & $330,000.00$ & $495,000.00$ & $412,500.00$ \\
\hline MCL7 & 168.19 & 336.38 & 1100 & 1650 & 1375 & $370,018.00$ & $555,027.00$ & $462,522.50$ \\
\hline MCL8 & 112.47 & 224.94 & 1100 & 1650 & 1375 & $247,434.00$ & $371,151.00$ & $309,292.50$ \\
\hline MCL9 & 200.32 & 400.64 & 1100 & 1650 & 1375 & $440,704.00$ & $661,056.00$ & $550,880.00$ \\
\hline
\end{tabular}

\section{Discussion}

The simulation analyses carried out demonstrate a strong difference in the feasibility of implementation of the two programs, given their economic conditions.

The blight elimination program simulation established that this type of program could be economically feasible and sustainable in the situations of real-estate decay that characterize the study area, and, more generally, the internal and peripheral areas affected 
by urban contraction phenomena within Italy [45]. The real-state value-zero in the case of the buildings under consideration, given their state of decommission-constrains the public costs (totaling 276,245.92 euros for the demolition of 17 buildings), which makes this option sustainable even when considering the financial capacity of the municipality. In the case examined, the application of the blight elimination program would produce positive effects in three distinct areas:

1. The securing of real-estate assets that present potential risks, both for people and for the surrounding buildings. Many of the abandoned buildings face public roads that are still in use or are adjacent to inhabited buildings, which creates dangerous conditions. The cost of securing these buildings through temporary support or renewal would be comparable to the demolition costs.

2. The requalification of the public urban space and of the landscape at a regional scale, which is nowadays strongly compromised by the presence of decommissioned real-estate.

3. The valorization of real-estate still in use, since these values are affected by the presence of buildings in a state of decay.

In the absence of planned public intervention, the examined decommissioned realestate assets are destined, at least in the medium-term, to remain in a state of decay and abandonment given that market prices in the area-on average 445 euro for $\mathrm{m}^{2}$-tend to be lower than the costs of the renovations necessary to renew the properties. This condition, common to many shrinking areas [46], limits the possibility of any real-estate investment aimed at enhancing the value of the buildings, therefore also limiting the possibilities of regeneration and reuse.

The results of the flood buyout program simulation are significantly different and express the economic hindrances in this program's application to the Italian context: the buyout simulation, limited to nine residential buildings with a regular conservation status, reached a cost of almost 3.5 million euros. A widespread application, encompassing more areas with similar risk characteristics and multi-family housing, would entail a sharp increase in costs that would need to be considered in decision-making, and would constitute a substantial economic and administrative impracticability. In addition to these aspects, it should be noted that the amount paid to the homeowners-given the average assessed market value - would be lower than the replacement value of the real-estate, and thus not sufficient to purchase another property with similar typological and dimensional characteristics in an area without risk. In that aspect, the punctual intervention hypothesized in the FBP simulation for the Italian case would not have meaningful effects in reducing the risk. The estimated costs of the buyout program are comparably lower than those regarding public works towards the mitigation and prevention of future hydrogeological events in the entire area, and therefore economically not justifiable.

\section{Conclusions}

In Italy, the extensive presence and diffusion of decommissioned assets, as well as those located within areas subjected to grave environmental risks, calls for careful considerations regarding the implementation of public policies aimed at their demolition, removal, and relocation.

In recent decades, urban and territorial regulations have restricted the construction of new real-estate assets in areas with systemic environmental hazards, therefore reducing the total number of structures subjected to risk. However, urban shrinking dynamicsresulting from an uneven territorial and economic development-increased the share of abandoned structures within the country, especially in small urban contexts, which in turn created vast areas characterized by structures with a high degree of physical and functional obsolescence. In this regard, the two kinds of real-estate assets-the decommissioned and the soon-to-be decommissioned due to territorial hazards-represent around $26 \%$ of the Italian real-estate stock, and have a negative impact on social, economic, and environmental aspects of the areas in which they exist, as well as their inhabitants. In light of these 
critical points, this study addresses and evaluates the applicability of two different urban demolition programs that are already in execution in the United States to an Italian context: Richmond's blight elimination program (BEP) and Nashville's flood buyout program (FBP), which have the objectives of eliminating decommissioned and obsolete real-estate assets, and relocating real-estate assets under environmental risk, respectively. The viability assessment was conducted through two simulations that applied the blight elimination program for the case of Lecce nei Marsi, in the L'Aquila province, and the flood buyout program for the case of Moncalieri in the Torino province. Both contexts were characterized by abandonment and flooding risks, respectively.

The simulations' results have demonstrated that there are wide differences concerning the applicability and, above all, the economic sustainability of the programs for the Italian context. The blight elimination program was verified as economically feasible, given that the estimated total costs are deemed reasonable when compared to the available funds of the local public authorities, especially in the projected scenario of execution. The flood buyout program exhibits significantly higher costs, mainly due to the necessity of realestate acquisitions at market value of structures that are still in use, which undermines its implementation, even from a long-term perspective. Regarding the FBP, even the if the analysis limits those acquisitions to only nine properties, total costs would be around 3.5 million Euros, a value already comparable to the total costs of securing the area through execution of public works for flood mitigation. This would ensure a greater area coverage, cost control, avoid potential disputes with the local population due to the proposed relocation. In this regard, there are also operational difficulties in relocating the population that could be reflected in economic terms, given that the market value is lower than the replacement cost of the asset. There is a real risk of a surge in costs in the local residential market, since in terms of urban planning, there would be a need to identify available building areas or to identify properties to be recovered.

The feasibility of the Italian case in the current scenario could be limited to the blight elimination programs, which is applicable due to the vast presence of decommissioned and obsolete real-estate assets that characterize the inner areas of the Italian territory, which has been affected by the structural phenomena of urban contraction. It is interesting to note that such programs could be easily integrated with the current Italian instruments of economic promotion and subsides for renewal and energy efficiency (i.e., the Building Bonuses, which reward the requalification of existent buildings with tax deductions that can reach up to $100 \%$ of the investment, and are also transferable to third parties). This could allow the definition of a new "demolition bonus" that could be implemented through the same bonus instruments, and be complementary to the framework of the existing subsides.

In this context, the potential application of BEP could be implemented in two different scenarios:

1. The first in the case where the demolished building is not rebuilt. In this case, we would be at the same level of applicability as the Richmond blight elimination program, and the incentive would consist of the public entity assuming the costs of demolition, along with the acquisition of the renaturalized area.

2. The second case would be in the event that the owner chooses to rebuild the building. In this case, the program would act as an incentive for recovery and the amount financed for demolition would be added to the building bonuses covering part of the general renovation cost. In this second scenario, the area would remain privately owned, and therefore, the amount disbursed could be reduced or proportionate to the achievement of quality objectives.

Although it is possible to acknowledge the role and feasibility of the blight elimination programs in the Italian case, some crucial knots remain to be unraveled before their effective implementation. Much of the decommissioned real-estate assets Italy are maintained, even if in a state of decay, in order to preserve the urban volume and the building capacity associated with the structure. Related to this, the tax exemptions for such units make 
a ruined building a reservoir of constructive rights and urban land at zero cost. This combination is at the core of the permanence of decommissioned real-estate assets, and a fundamental aspect in the resistance towards their demolition. In that sense, for the BEP to be successfully implemented, a combined modification of the taxation regime of disused buildings is necessary, along with the constitution of a "bank of building rights" that can guarantee the maintenance of building capacity even after demolition. This could be implemented in the urban and territorial equalization mechanisms already provided by the law. There is also the possibility of introducing a form of real-estate taxation that is conditional on participation in the program itself in areas where a BEP is active. This could encourage the start of requalification processes with a high rate of private participation, without placing a further burden on public funding.

Another knot to unravel exists at the governance scale. The burdensome nature of such programs and the complex administrative organization cannot be borne exclusively by municipal levels, but must necessarily be based on multi-level governance that embraces both supra and sub-local scales. In this context, the supra-local institution at a regional governance level could coordinate the general framework for the management of such programs, since it possesses the territorial planning powers, as well as the power to legislate within the framework of national regulations. At the sub-local level, on the other hand, it is fundamental to define several operational groups that could take charge of the material management of the program's implementation, mediating between the individual responsibilities of owners and technical professionals, and their institutional counterparts. In this sense, the constitution of public-private cooperatives, which in the past have constituted the backbone of Italian building growth (though not without some contradictions), could be relevant.

Finally, it is also important to mention the need for legislators to find a balance between the need for protection and the need for redevelopment, in order to integrate these aspects in the decision-making processes of the bodies responsible for territorial gestion and protection, a point that often represents a strong deterrent for investors to start renewal operations on existent assets. Ultimately, the results of this research expand the field of reflection on the recovery of disused assets, suggesting that it is possible to find forms of application of participatory urban planning that are economically sustainable and can achieve broad consensus and, consequently, adequate dissemination, which is essential to achieving significant results.

Author Contributions: Conceptualization, S.R. and V.D.P.; methodology, S.R. and V.D.P.; software, D.A. and V.D.P.; validation, D.A. and V.D.P.; formal analysis, S.R., D.A. and V.D.P.; investigation, S.R.; resources, S.R.; data curation, S.R.; writing—original draft preparation, S.R. and V.D.P.; writingreview and editing, S.R., V.D.P. and D.A.; visualization, D.A.; supervision, S.R.; project administration, S.R.; funding acquisition, S.R. Please turn to the CRediT taxonomy for the term explanations. All authors have read and agreed to the published version of the manuscript.

Funding: This research received no external funding.

Data Availability Statement: The data presented in this study are available on request from the corresponding author. The data are not publicly available due to privacy reasons.

Conflicts of Interest: The authors declare no conflict of interest. The funders had no role in the design of the study; in the collection, analyses, or interpretation of data; in the writing of the manuscript, or in the decision to publish the results.

\section{References}

1. Molotch, H. The city as a growth machine: Toward a political economy of place. Am. J. Sociol. 1976, 82, 309-332. [CrossRef]

2. Martinez-Fernandez, C.; Audirac, I.; Fol, S.; Cunningham-Sabot, E. Shrinking Cities: Urban Challenges of Globalization. Int. J. Urban Reg. Res. 2012, 36, 213-225. [CrossRef] [PubMed]

3. Mississippi Home Corporation. Blight Elimination Program-Application Workshop. Available online: https://archivemhc. $\mathrm{com} / \mathrm{hhf} /$ (accessed on 7 July 2021). 
4. U.S. Department of the Treasury. Hardest Hit Fund Program Allocations: State Expense Allocations. Available online: https: / / home.treasury.gov/system/files/256/Program-Allocations.pdf (accessed on 7 July 2021).

5. Medeiros, E.; Brandão, A.; Pinto, P.; Lopes, S. Urban Planning Policies to the Renewal of Riverfront Areas: The Lisbon Metropolis Case. Sustainability 2021, 13, 5665. [CrossRef]

6. Jaszczak, A.; Kristianova, K.; Pochodyła, E.; Kazak, J.; Młynarczyk, K. Revitalization of Public Spaces in Cittaslow Towns: Recent Urban Redevelopment in Central Europe. Sustainability 2021, 13, 2564. [CrossRef]

7. Taboada, G.; Seruca, I.; Sousa, C.; Pereira, A. Exploratory Data Analysis and Data Envelopment Analysis of Construction and Demolition Waste Management in the European Economic Area. Sustainability 2020, 12, 4995. [CrossRef]

8. Mobley, W.; Atoba, K.; Highfield, W. Uncertainty in Flood Mitigation Practices: Assessing the Economic Benefits of Property Acquisition and Elevation in Flood-Prone Communities. Sustainability 2020, 12, 2098. [CrossRef]

9. Pallagst, K. Das Ende der Wachstumsmashine. Berl. Debatte Initial. 2007, 18, 4-13.

10. Hackworth, J. Demolition as urban policy in the American Rust Belt. Environ. Plan. A 2016, 48, 2201-2222. [CrossRef]

11. Peterson, B. Demolition Space and Housing Removal Policy in Detroit. Master's Thesis, Department of Urban Studies and Planning-Massachusetts Institute of Technology, Cambridge, MA, USA, June 2018.

12. Ammon, F.R. Bulldoze: Demolition and Clearence of the Postwar Landascape; Yale University Press: London, UK; New Heaven \& London: London, UK, 2016.

13. Lavagna, M. Life Cycle Assessment in Edilizia. Progettare e Costruire in una Prospettiva di Sostenibilità Ambientale; Hoepli: Milano, Italy, 2008.

14. Bekker, P. A Life-cycle Approach in Building. Build. Environ. 1982, 17, 55-61. [CrossRef]

15. Fraser, W.D. Principles of Property Investment and Pricing, 1st ed.; Palgrave: London, UK, 1984.

16. Golton, B.L. Perspectives of building obsolescence. In Land and Property Development. New Directions; Grover, R., Ed.; Spon: London, UK, 1989; pp. 269-280.

17. Fera, I. Complessità e contraddizioni nella demolizione. In Territori dell'Abusivismo. Un Progetto per Uscire dall'Italia dei Condone; Curci, F., Formato, E., Zanfi, F., Eds.; Donzelli: Rome, Italy, 2017; pp. 97-112.

18. Rusci, S.; Perrone, M.A. The city to be demolished. A case study for the analysis of demolition and urban contraction costs in Italy. Valori Valutazioni 2020, 26, 59-71. [CrossRef]

19. Griswold, N.; Calnin, B.; Schramm, M.; Anselin, L.; Boehnlein, P. Estimating the Effect of Demolishing Distressed Structures in Cleveland, OH, 2009-2013: Impacts on Real Estate Equity and Mortgage_Foreclosure; Thriving Communities Institute: Moreland Hills, OH, USA, 2014.

20. Merlini, C. Demolition as a Territorial Reform Project. In Regeneration of the Built Environment from a Circular Economy Perspective. Research for Development, 1st ed.; Della Torre, S., Cattaneo, S., Lenzi, C., Zanelli, A., Eds.; Springer: Cham, Switzerland, 2020; pp. 39-45.

21. Picon, A. Tra Utopia e Ruggine. Paesaggi dell'Ingegneria dal Settecento a Oggi; Piccoli, E., Ed.; Allemandi: Torino, Italy, 2006.

22. Clement, A. Manifesto del Terzo Paesaggio; De Pieri, F., Ed.; Quodlibet: Macerata, Italy, 2004.

23. ISTAT. Forme, Livelli e Dinamiche dell'Urbanizzazione in Italia; Istituto Nazionale di Statistica: Roma, Italy, 2017.

24. Guerrieri, G.; Angelini, A. I fabbricati collabenti: Stock e distribuzione territoriale, Quaderni dell'Osservatorio. Appunti Econ. Immob. 2019, VII, 8-18.

25. Lanzani, A.; Merlini, C.; Zanfi, F. Quando 'un nuovo ciclo di vita' non si dà. Fenomenologia dello spazio abbandonato e prospettive per il progetto urbanistico oltre il paradigma del riuso. Arch. Studi Urbani Reg. 2014, 109, 28-47. [CrossRef]

26. Nelson, K.; Camp, J. Quantifying the Benefits of Home Buyouts for Mitigating Flood Damages. Anthropocene 2020, $31,100246$. [CrossRef]

27. Peterson, C.; Apadula, E.; Salvesen, D.; Hino, M.; Kihslinger, R.; BenDor, T. A Review of Funding Mechanisms for US Floodplain Buyouts. Sustainability 2020, 12, 10112. [CrossRef]

28. Dynamo Metrics. Estimating Home Equity Impacts from Rapid, Targeted Residential Demolition in Detroit, MI: Application of a Spatially-Dynamic Data System for Decision Support. Available online: http://www.demolitionimpact.org/s/Detroit_ DemoStudy_FinalEditedVersion.pdf (accessed on 7 July 2021).

29. Trigila, A.; Iadanza, C.; Bussettini, M.; Lastoria, B. Dissesto idrogeologico in Italia: Pericolosità e indicatori di rischio; Rapporto 287/2018; ISPRA: Roma, Italy, June 2018.

30. European Commission-Copernicus Global Land Service. CORINE Land Cover (CLC) Inventory-Reference Year 2018. Available online: https: / / land.copernicus.eu/pan-european/corine-land-cover/clc2018 (accessed on 7 July 2021).

31. European Commission-Copernicus Global Land Service. Urban Atlas—Reference Year 2018. Available online: https://land. copernicus.eu/local/urban-atlas/urban-atlas-2018 (accessed on 7 July 2021).

32. Zoboli, R.; Modica, M.; Paleari, S.; Marin, G.; Elisabetta Genovese, E.; Rampa, A.; Salvati, P.; Marchesini, I.; Rossi, M.; Donnini, M.; et al. La Valutazione Economica dei Disastri Naturali in Italia-Rapporto sui Principali Risultati; IRCrES-CNR: Roma, Italy, January 2018.

33. Genovese, E. Le Alluvioni in Italia: Verso un Mosaico di Interventi Integrati per la Mitigazione del Rischio. In Mosaico; Cerruti, S., Tadini, M., Eds.; Società di Studi Geografici: Firenze, Italy, 2019; pp. 521-527.

34. ANCI-Cresme Data. Available online: https:// costi-costruzione.cresme.it/default.aspx (accessed on 7 July 2021). 
35. U.S. Department of the Treasury. Hardest Hit Fund. Four Quarter 2020 Performance Summary. Available online: https://home. treasury.gov/system/files/256/Q4-2020-Hardest-Hit-Fund-Program-Performance-Summary.pdf (accessed on 7 July 2021).

36. Sagamore Institute. Indiana Blight Elimination Program Research Evaluation Study 2018. Available online: http://www.inbep. org/2019inbepimpactanalysis-457492.html (accessed on 7 July 2021).

37. Freudenberg, R.; Calvin, E.; Tolkoff, L.B. Buy-In for Buyouts; Policy Focus Report; Lincoln Institute of Land Policy: Cambridge, MA, USA, 2016.

38. Natural Hazard Mitigation Saves 2017 Interim Report: An Independent Study—Summary of Findings; National Institute of Building Sciences: Washington, DC, USA, 2017.

39. Weber, A.; Moore, R. Going Under: Long Wait Times for Post-Flood Buyouts Leave Homeowners Underwater; Natural Resource Defense Council: New York City, NY, USA, 2019.

40. Google Maps. Available online: https://www.google.it/maps/ (accessed on 1 July 2021).

41. Google Earth. Available online: Earth.google.com/web/ (accessed on 1 July 2021).

42. ISPRA. Mosaicatura ISPRA (2017) delle Aree a Pericolosità Idraulica—Scenari D; Lgs. 49/2010; ISPRA: Rome, Italy, December 2017.

43. Open Bilanci. Available online: https:/ / openbilanci.it/ (accessed on 1 July 2021).

44. Agenzia delle Entrate. Osservatorio del Mercato Immobiliare-Banca dati Delle Quotazioni OMI Periodo 2002-2020; Agenzia delle Entrate: Roma, Italy, 2021.

45. Crisci, M.; Gemmiti, R.; Proietti, E.; Violante, A. Urban Sprawl e Shrinking Cities in Italia. Trasformazione Urbana e Redistribuzione della Popolazione Nelle Aree Metropolitane; CNR-IRPPS: Roma, Italy, 2014.

46. Glaeser, E.; Gyourko, J. Urban Decline and Durable Housing. J. Political Econ. 2005, 113, 345-400. [CrossRef] 